\title{
RADIOGRAPHIC STUDY OF PATIENTS SUBMITTED TO TOTAL GASTRECTOMY USING SAFATLE RECONSTRUCTION TECHNIQUE
}

\author{
Alberto Luiz Monteiro MEYER ${ }^{1}$, Eduardo BERGER ${ }^{1}$, Orlando MONTEIRO Jr. ${ }^{1}$, \\ Paulino Alberto ALONSO ${ }^{1}$ and João Sadi LERNER ${ }^{2}$
}

\begin{abstract}
Background - Ever since the first total gastrectomy, there has always been a great concern in increasing the survival of patients, and with the advance of techniques, in improving the quality of life of these patients. The most common reconstruction technique of the gastrointestinal transit is the Roux-en-Y. The reposition of a functional pouch in place of the resected stomach was proposed to minimize the postprandial symptoms, improve the nutritional grade and consequently, the quality of life. The Safatle reconstruction of the gastrointestinal transit technique consists of, in short, in the association of the interposition of the jejunal loop with partial transit through the duodenum, with an inverted Roux-en-Y and with the creation of a pouch which resembles the dynamics of the stomach, achieved by duodenojejunal segment which has an antiperistalsis emptying. Aim - To assess, by radiographic means, the emptying of the duodenojejunal pouch in patients submitted to total gastrectomy using the Safatle reconstruction technique. Method - Twelve patients submitted to total gastrectomy using the Safatle technique due to gastric cancer were studied. They were summoned to perform contrasted radiographies of the esophagusduodenum-jejunum by the videofluoroscopic method during the months of July and August, 2005. Results - All the patients presented satisfactory movement of the duodenojejunal pouch and an adequate emptying in antiperistalsis without food stasis. There has been an average 25-minute drainage time of the duodenojejunal pouch. Conclusion - The duodenojejunal pouch, in the patients submitted to total gastrectomy using the Safatle reconstruction, presented adequate emptying and movement.
\end{abstract}

HEADINGS - Gastrectomy. Gastric emptying. Anastomosis, Roux-en-Y. Stomach neoplasms, radiography. Radiography, abdominal.

\section{INTRODUCTION}

Péan $(1879)^{(6)}$ performed the first gastric resection due to pylorus cancer with gastroduodenal anastomosis. The patient died 6 hours after the surgery.

In 1880 , Rydygier ${ }^{(6)}$ used the same technique idealized by Péan. The patient died 4 hours after.

Billroth $(1881)^{(5)}$, performing the same Péan technique, accomplished the first survival case of gastrectomy, called Pean-Billroth or Billroth I. In 1885, Billroth, after operating pylorus cancer with precolic gastroduodenal anastomosis, submitted the patient to a new surgery when resected the tumor and closed up the duodenum (Billroth II) ${ }^{(5)}$.

Kronlen $^{(6)}$, in 1887 , trying to increase the survival and diminish the mortality, proposed an easier-execution technique, performing the first partial gastrectomy with gastroduodenal anastomosis with oralis totalis .

With the advance of suture techniques, Schlater (1897) (16), performed the first successful total gastrectomy with survival of the patient.

Roux $(1893)^{(5)}$, intending to obtain better indices of survival in the post operation, proposed resection in Y, that is, an end-to-side esophagojejunal anastomosis, in which the afferent loop is sectioned and anastomosed 40 $\mathrm{cm}$ of the efferent loop.

Since the first total gastrectomy, there has always been a concern in increasing the survival and, with the advance of the techniques, in improving the quality of life ${ }^{(5,14)}$.

The most accepted technique for the reconstruction of the intestinal transit after total gastrectomy is the Roux-en-Y due to the prevention of peptic esophagitis as well as permitting a tension-free anastomosis ${ }^{(1,3,10)}$. Nevertheless, the weight loss, malnutrition and post operation symptoms, such as postprandial completeness, early satiety and dumping syndrome are common after this reconstruction and impair significantly the quality of life ${ }^{(7,8)}$.

The reposition of a functional pouch in the place of the resected stomach was proposed by various authors to minimize the postprandial symptoms, increase the nutritional grade and consequently the quality of life ${ }^{(18)}$.

The total removal of the stomach does not implicate the inconsistency with life, but it threatens its quality since it can be followed by important morbidness. The 
idea of substituting the stomach for a pouch happened due to the need of amplifying the capacity of storing the food and allowing a better usage of it. Thinking of that, SAFATLE ${ }^{15}$, in 1984, idealized a method that comprised an easy technique and reduced the indices of complications as well improving the quality of life, especially regarding the nutritional grade.

This technique consists, in short, in an association of the interposition of the jejunal loop with partial transit through the duodenum with an inverted Roux-en-Y (omega) and with the creation of a pouch that resembles the dynamics of the stomach achieved by duodenojejunal segment which has an antiperistalsis emptying ${ }^{(15)}$.

The pendular movement of the second portion of the duodenum, intensified by the interruption of the jejunal loop avoids gastroparesis and therefore the blind loop syndrome. This change makes the contents to empty in a slower manner, thanks to the interposition of the loop. The 30-centimeter distance between the two anastomosis impedes the peptic esophagitis, and the incorporation of the duodenum arch in the transit creates greater opportunities for a better absorption of the nutrients. Besides, it allows if necessary, an endoscopic approach of the duodenum.

The study of the gastric emptying is effective to test the efficiency of a drug or surgical therapeutic. The videofluoroscopic method evaluation has the advantage of documenting the dynamics phenomema in real time and admits, though the recordings, a minute analysis of the organ movement and the dynamics of its emptying ${ }^{(4)}$.

The aim of this study is assessing, by radiographic means, the emptying of the duodenojejunal pouch in patients submitted to total gastrectomy using the Safatle reconstruction technique.

\section{METHOD}

A retrospective transversal study of gastric-cancer patients was carried out between 1995 and 2005. All of the patients were submitted to total gastrectomy at the "Prof. Edmundo Vasconcelos" Hospital General Surgery Service, São Paulo, SP, Brazil.

Thirty-six patients were selected according to ambulatory files and medical record of internment. The patients had their diagnoses confirmed in the preoperative, through the digestive system endoscopy with biopsy and computed tomography of thorax and abdomen. The abided staging was that authorized by International Union Against Cancer (UICC, 1987) using TNM ${ }^{(19)}$.

Out of the 36 patients, 4 live in a different State, 9 did not present the address and/or telephone number compatible to those in their medical records and 1 did not agree to participate in the study. Therefore, 12 patients submitted to total gastrectomy using the Safatle technique, in regular ambulatory supervision, were studied.

The criteria of exclusion were: the presence of concomitant neoplasms, neoadjuvant therapy, neoplasm recurrence and those who did not agree with the program.

The patients were summoned to perform contrasted radiographies of the esophagus-duodenum-jejunum by videofluoroscopic method, using a seriograph with a TV system. The images acquired were recorded in CD during the months of July and August of 2005.
The same radiologist performed the contrasted radiographies, after an 8-hour fast and the ingestion of $150 \mathrm{~mL}$ of barium sulfate (commercial gel per 100\%) and sequenced radiographies (videofluoroscopic method) were made until the emptying of the content of the duodenojejunal pouch.

The Medical Ethics Committee of "Prof. Edmundo Vasconcelos" Hospital approved the protocol of this study.

\section{RESULTS}

This study group consisted of 12 patients of average age of 58.62 , varying from 26 to 80 years old. All of the patients were submitted to total gastrectomy, being eight $(66.6 \%)$ males and four $(33.4 \%)$ females.

The anatomy pathologic reports of these patients consisted of gastric adenocarcinoma with II and III clinical staging according to the TNM classification.

The time elapsing the surgery and the present study varied from 4 months to 8 years.

The study of the contrasted radiographies of the esophagusduodenum-jejunum showed the adequate transit of the contrast means through the esophagus and esophagojejunal anastomosis in $100 \%$ of the patients (Figure 1).

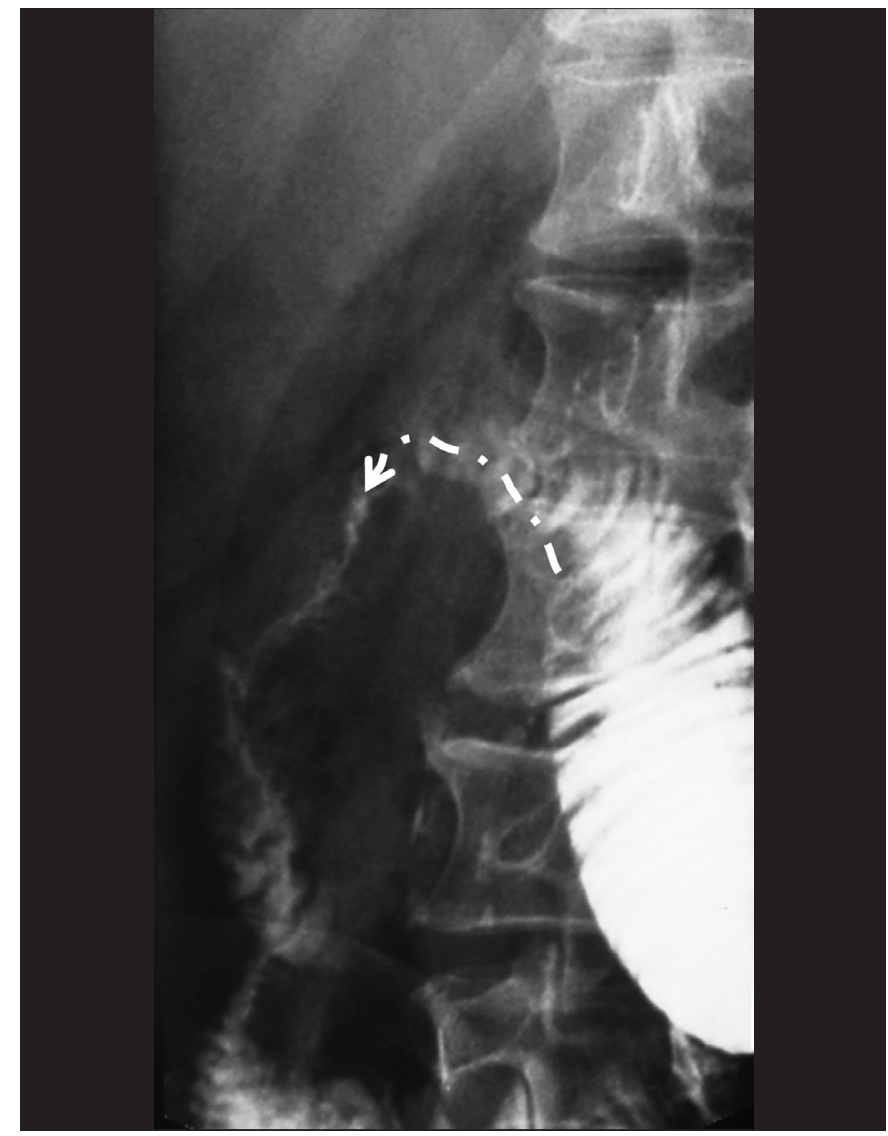

FIGURE 1. Contrasted radiography showing duodenojejunal anastomosis 
The duodenojejunal anastomosis also did not present alterations in the movement. All of the patients presented satisfactory movement of the duodenojejunal pouch (Figure 2) with adequate emptying in antiperistalsis without food stasis.

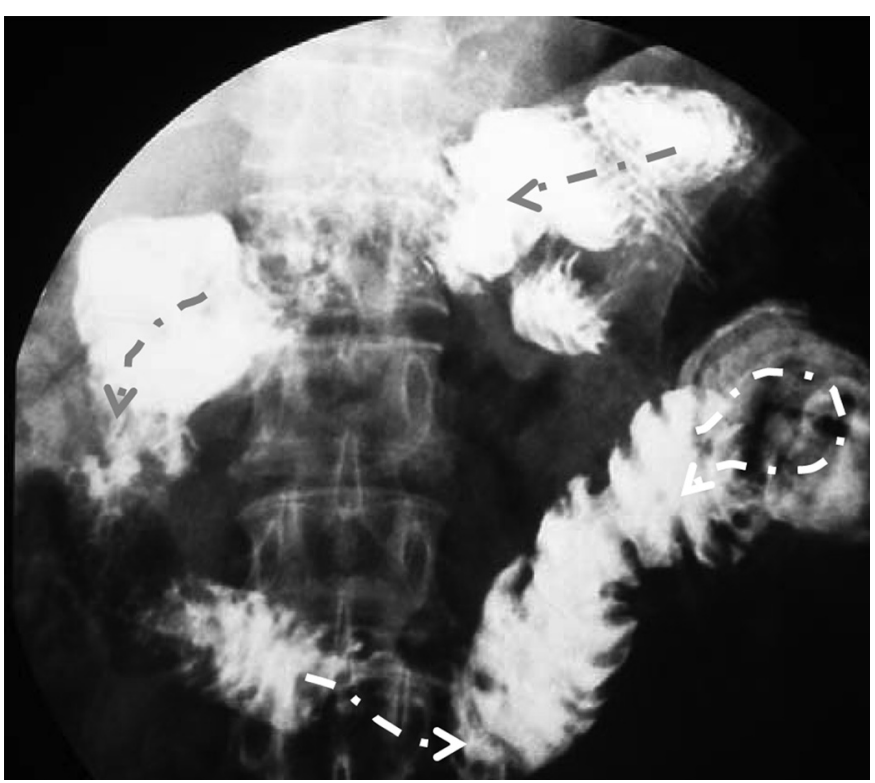

FIGURE 2. Contrasted radiography showing duodenojejunal pouch

By analyzing the results of the contrasted radiographies, it was observed that the time for the emptying of the duodenojejunal pouch was of 25 minutes in average (Table 1 and Figure 3).

TABLE 1. Emptying time of the duodenojejunal pouch

\begin{tabular}{lcc}
\hline Patient & $\begin{array}{c}\text { Surgery } \\
\text { (months) }\end{array}$ & $\begin{array}{c}\text { Transit time } \\
\text { (minutes) }\end{array}$ \\
\hline 1 & 4 & 21 \\
2 & 6 & 26 \\
3 & 10 & 15 \\
4 & 17 & 24 \\
5 & 26 & 22 \\
6 & 29 & 26 \\
7 & 34 & 27 \\
8 & 38 & 26 \\
9 & 49 & 28 \\
10 & 63 & 30 \\
11 & 73 & 28 \\
12 & 98 & 27 \\
\hline
\end{tabular}

\section{DISCUSSION}

Physiologically, the distal stomach mix, grinds and propels the contents. The patients submitted to total gastrectomy lose this function, however, those submitted to the reconstruction with the antiperistalsis duodenojejunal pouch do not lose it totally, since the peristalsis and antiperistalsis movements of the duodenum allow the food to be mixed to the biliopancreatic enzymes, acting as well as a pouch to the food content ${ }^{(2)}$.

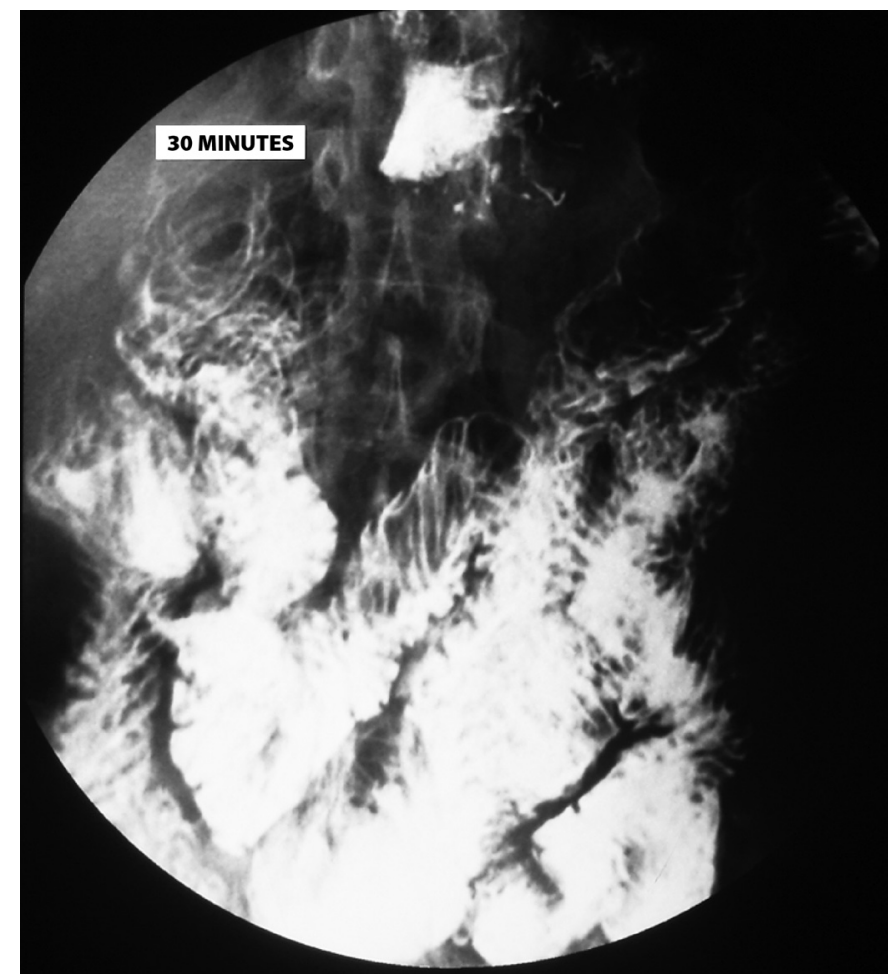

FIGURE 3. Contrasted radiography with contrast in the jejunum showing the emptying time of the duodenojejunal pouch

The significant improvement of the nutritional status of the patients submitted to gastrectomy using the Safatle technique, in comparison to other techniques, consists of an important characteristic, and it is well established. The patients gain weight, even without a stomach, and do not have important gastrointestinal complaints. The advantages of the reconstruction with the duodenojejunal pouch over the Roux-en-Y was also confirmed by various authors ${ }^{(12,13)}$.

The regular stomach has a variable emptying time according to the type of food. The intake of liquid food allows an emptying time of approximately 30 minutes. For solid food, this time increases varying from 1 to 2 hours ${ }^{(11)}$. During the performance of the contrasted radiography, the patient ingests liquid (barium contrast); therefore, it was observed that, from the 12 patients studied, the emptying time of the stomach content was similar to that of the stomach. Aside from this, there was no evidence of disturbances in the movement of the duodenojejunal pouch.

JIVONEN et al. ${ }^{(9)}$ comparing the observed time of emptying in patients submitted to total gastrectomy with reconstruction by jejunal pouch and by Roux-en-Y, demonstrated that the jejunal pouches substitute the resected stomach, reduce the typical symptoms of the Roux-en-Y reconstruction (dumping, nausea and vomiting, diarrhea), and maintain the nutritional balance.

This same authors compared the time of emptying in both liquid and solid food groups, the latter was possible due to usage of meals containing technetium $(\mathrm{Tc} 00 \mathrm{~m})$. The conclusion was that, as for liquid as for solid food, the emptying time was greater in the jejunal pouch, which by its turn, presented similar to the regular stomach. 
The losing of weight in patients submitted to total gastrectomy corresponds to the loss of the adipose reserve and muscle mass, as well as anemia is commonly verified. The deficiency of iron results of its inadequate ingestion, of the exclusion of the duodenum (Roux-en-Y) that is the main place of iron absorption and the rapid passage of the food to the intestines ${ }^{(17)}$. The total removal of the stomach, which has mechanical and organic primordial functions, brings serious consequences to the patients, principally the protein-energetic malnutrition. The duodenojejunal pouch substitutes the stomach and includes the duodenum in the transit, and consequently, promotes a better absorption of nutrients and nutritional support.

The analysis of the emptying time of the duodenojejunal pouch is of fundamental importance to the success of the reconstruction technique, since the delay in the emptying and the remaining of the food in the pouch will allow a better nutritional status of the patient.

The question, regarding the duodenojejunal pouch, was the presence or not of food stasis, since it is a "blind loop", and which was not observed in our study. The barium presented an adequate emptying in antiperistalsis (pendular movement of the duodenum) without retention in the duodenojejunal pouch.

\section{CONCLUSION}

The duodenojejunal pouch in the patients submitted to total gastrectomy using the Safatle reconstruction technique presented an adequate emptying and movement.

Meyer ALM, Berger E, Monteiro Jr O, Alonso PA, Lerner JS. Estudo radiológico em doentes submetidos a gastrectomia total com reconstrução à Safatle. Arq Gastroenterol. 2008;45(3):230-3.

RESUMO - Racional - Desde a primeira gastrectomia total, houve sempre a preocupação em aumentar a sobrevida e, com o aprimoramento das técnicas, de melhorar a qualidade de vida. A técnica mais aceita para a reconstrução do trânsito intestinal após gastrectomia total é a em Y-de-Roux. A reposição de um reservatório funcional no lugar do estômago ressecado foi proposta para minimizar os sintomas pós-prandiais, melhorar o grau nutricional e, conseqüentemente, a qualidade de vida. A técnica de reconstrução do trânsito intestinal pós-gastrectomia à Safatle consiste, em síntese, numa associação da interposição de alça jejunal com trânsito parcial pelo duodeno, com o Y-de-Roux invertido, e com a criação de um reservatório que se aproxima da dinâmica do estômago, obtido à custa de um segmento duodenojejunal com esvaziamento em antiperistalse. Objetivo - Avaliar, por método radiológico, o esvaziamento da bolsa duodenojejunal em doentes submetidos a gastrectomia total com reconstrução à Safatle. Método - Foram estudados 12 doentes submetidos a gastrectomia total por câncer gástrico com reconstrução à Safatle, convocados para realizar radiografias contrastadas de esôfago-duodeno-jejuno pelo método videofluoroscópico nos meses de julho a agosto de 2005. Resultados - Todos os doentes apresentaram motricidade satisfatória da bolsa duodenojejunal com adequado esvaziamento em antiperistalse sem estase alimentar. O tempo de esvaziamento da bolsa duodenojejunal foi de 25 minutos em média. Conclusão - A bolsa duodenojejunal, nos doentes submetidos a gastrectomia total com reconstrução à Safatle, apresentou adequado esvaziamento e motricidade.

DESCRITORES - Gastrectomia. Esvaziamento gástrico. Anastomose em Y-de-Roux. Neoplasias gástricas, radiografias. Radiografia abdominal.

\section{REFERENCES}

1. Allen AW. Total gastrectomy for carcinoma of the stomach. Am J Surg. 1938;40:35

2. Cullen JJ, Kelly KA. Gastric motor physiology and pathophysiology. Surg Clin North Am. 1993;73:1145-60.

3. Finney JM, Rienhoff WF. Gastrectomy. Arch Surg. 1929;18:140-62.

4. Firman $\mathrm{CMG}$, Costa MMB, Costa ML, Lemme E. Qualitative and quantitative evaluation of the gastric emptying by the videofluoroscopic method. Arq Gastroenterol. 2000;37:81-8

5. Goffi FS, Bromberg HS. Gastrectomias sub-totais e totais. In: Goffi FS, editor. Técnica cirúrgica bases anatômicas, fisiopatológicas e técnicas da cirurgia. 4a ed. São Paulo: Atheneu; 2004. p.568-75.

6. Gonçalves MPS. Avaliação nutricional em pacientes com câncer gástrico operados com bolsa duodenojejunal antiperistáltica no período de 3 a 5 anos. [Dissertação]. São Paulo: Escola Paulista de Medicina; 2001.

7. Iesato H, Ohya T, Ohwada S, Itagaki S, Yokomori T, Morishita Y. Jejunal pouch interposition with an antiperistaltic conduit as a pyloric ring substitute after standard distal gastrectomy: a comparison with the use of an isoperistaltic conduit. Hepatogastroenterology. 2000;47:756-60.

8. Jivonen MK, Koskinen MO, Ikonen TJ, Matikainen MJ. Emptying of the jejunal pouch and Roux-en-Y limb after total gastrectomy - a randomized, prospective study. Eur J Surg. 1999;165:742-7.

9. Jivonen MK, Mattila JJ, Nordback IH, Matikainen MJ. Long-term follow-up of patients with jejunal pouch reconstruction after total gastrectomy. Scand J Gastroenterol. 2000;35:679-85

10. Lahey FH. Complete removal of the stomach for malignancy. Surg Gynecol Obstet. $1935 ; 67: 213-23$
11. Malagelada JR, Robertson JS, Brown ML, Remington M, Duenes JA, Thomforde GM, Carryer PW. Intestinal transit of solid and liquid components of a meal in health. Gastroenterology. 1984;87:1255-63.

12. Morii Y, Arita T, Shimoda K, Yasuda K, Matsui Y, Inomata M, Kitano S. Jejunal interposition to prevent postgastrectomy syndromes. Br J Surg. 2000;87:1576-9.

13. Nomura E, Shinohara H, Mabuchi H, Sang-Woong L, Sonoda T, Tanigawa N. Postoperative evaluation of the jejunal pouch reconstruction following proximal and distal gastrectomy for cancer. Hepatogastroenterology. 2004;51:1561-6.

14. Raia AA, Garrido Junior AA, Mello JB. Úlcera gastroduodenal. In: Raia AA, Zerbini, editors. Clínica cirúrgica Alípio Correa Netto. São Paulo: Sarvier; 1998. p.262-307.

15. Safatle NF. Bolsa duodenojejunal antiperistáltica na reconstrução do trânsito digestivo após gastrectomia subtotal, total e na síndrome pós-gastrectomia. Técnica. Arq Gastroenterol. 1984;21:59-67.

16. Schlatter $\mathrm{K}$. A unique case of complete removal of the stomach: successful esophagoenterostomy recovery. Med Rec. 1897;52:909-14.

17. Stäel von Holstein C, Walther B, Ibrahimbegovic E, Akesson B. Nutritional status after total and partial gastrectomy with Roux-en-Y reconstruction. Br J Surg. 1991;78:1084-7

18. Tanaka T, Kusunoki M, Fujiwara Y, Nakagawa K, Utsunomiya J. Jejunal pouch length influences metabolism after total gastrectomy. Hepatogastroenterology. 1997;44:891-6.

19. UICC Union Internationale Contre le Cancer. TNM classification of malignant tumors. 3rd ed. Geneva: UICC; 1982. p.63-7. 